Report of Investigation 2019-3

\title{
REGIONAL TSUNAMI HAZARD ASSESSMENT FOR FALSE PASS AND PERRYVILLE, ALASKA
}

E.N. Suleimani, J.B. Salisbury, D.J. Nicolsky, and R.D. Koehler

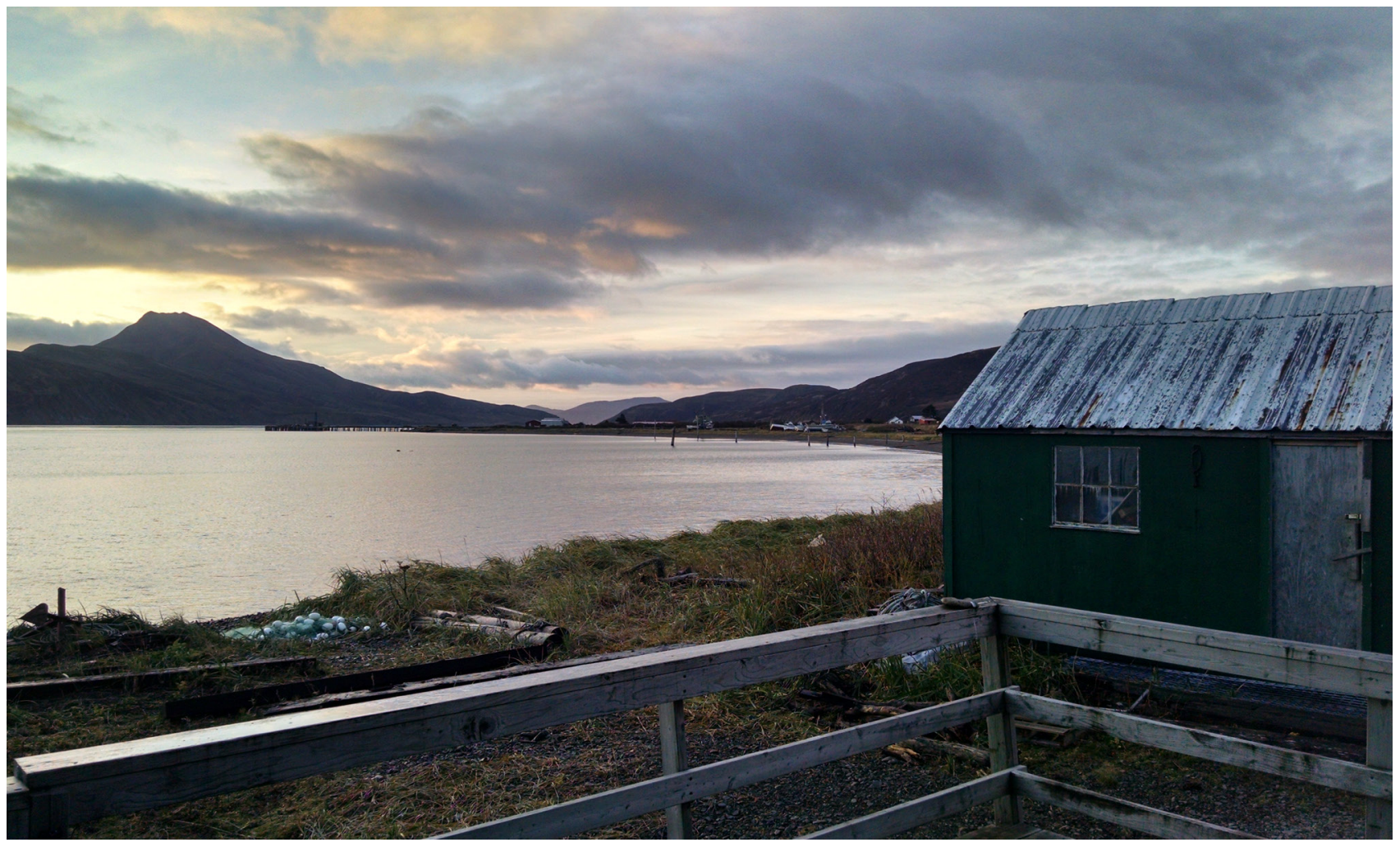

False Pass, Alaska. Photo: Amy Macpherson.

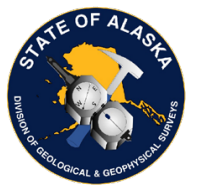





\section{REGIONAL TSUNAMI HAZARD ASSESSMENT FOR FALSE PASS AND PERRYVILLE, ALASKA}

E.N. Suleimani, J.B. Salisbury, D.J. Nicolsky, and R.D. Koehler

Report of Investigation 2019-3

State of Alaska

Department of Natural Resources

Division of Geological \& Geophysical Surveys 
STATE OF ALASKA

Michael J. Dunleavy, Governor

\title{
DEPARTMENT OF NATURAL RESOURCES
}

Corri A. Feige, Commissioner

\section{DIVISION OF GEOLOGICAL \& GEOPHYSICAL SURVEYS}

\author{
Steve Masterman, State Geologist and Director
}

Publications produced by the Division of Geological \& Geophysical Surveys (DGGS) are available for free download from the DGGS website (dggs.alaska.gov). Publications on hard-copy or digital media can be examined or purchased in the Fairbanks office:

Alaska Division of Geological \& Geophysical Surveys 3354 College Rd., Fairbanks, Alaska 99709-3707

Phone: (907) 451-5010 Fax (907) 451-5050

dggspubs@alaska.gov|dggs.alaska.gov

DGGS publications are also available at:

Alaska State Library,

Historical Collections \& Talking Book Center

395 Whittier Street

Juneau, Alaska 99811

Alaska Resource Library and Information Services (ARLIS)

3150 C Street, Suite 100

Anchorage, Alaska 99503

\section{Suggested citation:}

Suleimani, E.N., Salisbury, J.B., Nicolsky, D.J., and Koehler, R.D., 2019, Regional tsunami hazard assessment for False Pass and Perryville, Alaska: Alaska Division of Geological \& Geophysical Surveys Report of Investigation 2019-3, 16 p., 2 sheets. doi.org/10.14509/30192
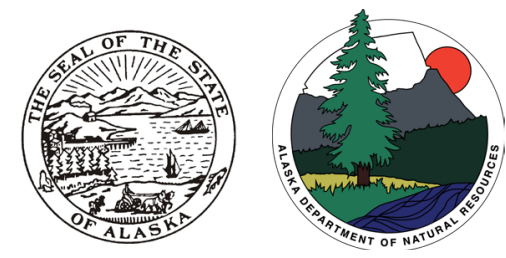


\section{Contents}

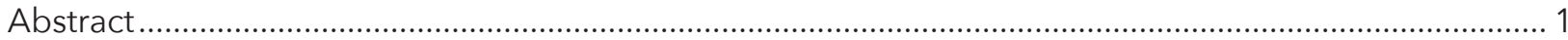

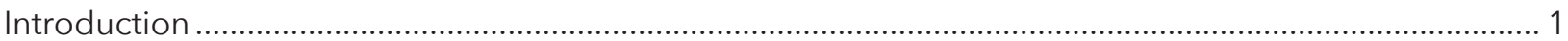

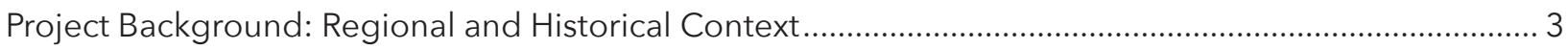

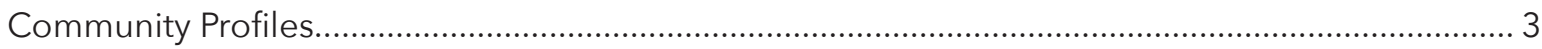

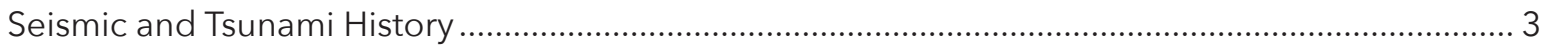

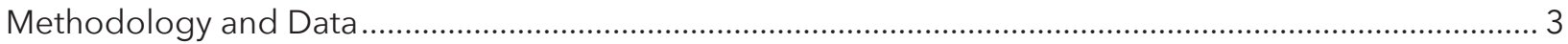

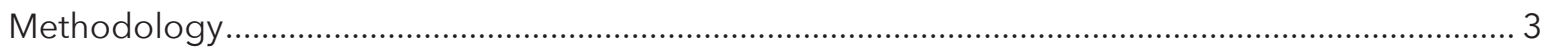

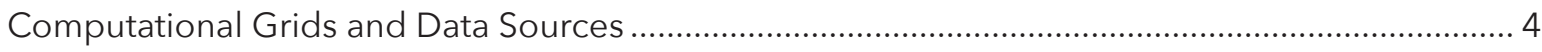

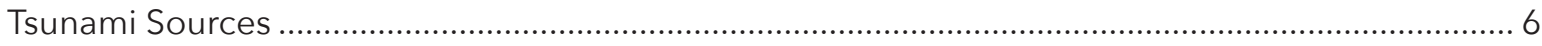

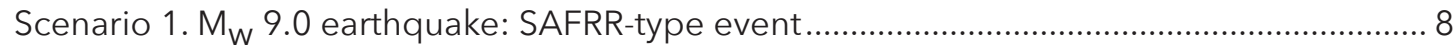

Scenario 2. $\mathrm{M}_{\mathrm{W}} 9.0$ earthquake: Maximum slip at 15-25 km (9-15 mi) depth........................ 9

Scenario 3. $\mathrm{M}_{\mathrm{W}} 9.0$ earthquake: Maximum slip at 25-35 km (15-22 mi) depth ..................... 9

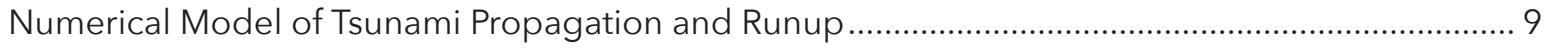

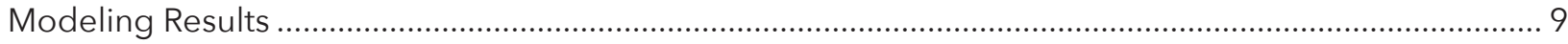

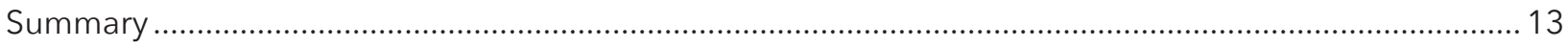

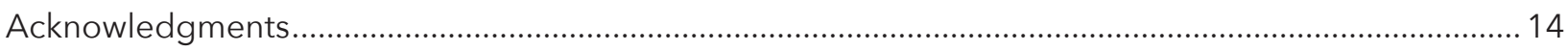

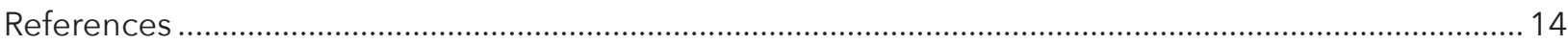

\section{Figures}

Figure 1. Map of the western Alaska Peninsula and eastern Aleutian Islands .......................................... 2

Figure 2. Nested bathymetry/topography grids for numerical modeling of tsunami

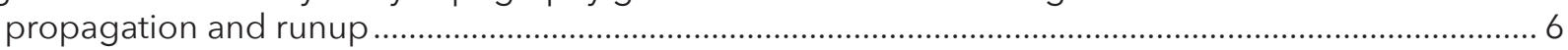

Figure 3. Vertical coseismic deformations corresponding to scenarios 1-3 ......................................... 7

Figure 4. Maximum tsunami height for scenarios 1-3 in the level 3 grid for False Pass ......................... 10

Figure 5. Maximum tsunami height for scenarios 1-3 in the level 3 grid for Perryville............................ 11

Figure 6. Maximum composite tsunami height for False Pass ................................................................ 12

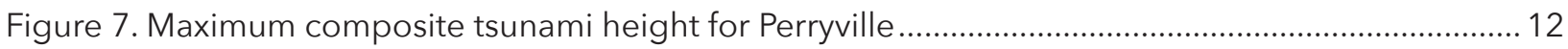

Figure 8. Time series of water level for scenarios 1-3 at False Pass and Perryville ................................. 13

\section{Tables}

Table 1. Tsunami effects at False Pass and Perryville ............................................................................. 4

Table 2. Nested grids used to compute propagation of tsunami waves generated in the Pacific

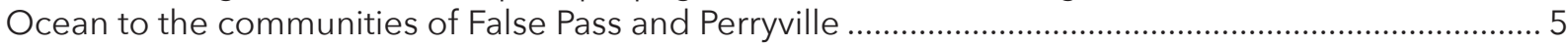

Table 3. Significant credible tsunami sources for False Pass and Perryville................................................ 8

\section{Map Sheets}

Sheet 1. Tsunami hazard map for False Pass, Alaska

Sheet 2. Tsunami hazard map for Perryville, Alaska 



\title{
REGIONAL TSUNAMI HAZARD ASSESSMENT FOR FALSE PASS AND PERRYVILLE, ALASKA
}

\author{
E.N. Suleimani, ${ }^{1}$ J.B. Salisbury, ${ }^{2}$ D.J. Nicolsky, ${ }^{1}$ and R.D. Koehler ${ }^{3}$
}

\begin{abstract}
We assess potential tsunami hazard for the coastal communities of False Pass on Unimak Island and Perryville on the Alaska Peninsula. The primary tsunami hazard for these communities is considered to be near-field, with the major threat originating from tsunamigenic earthquakes along the Alaska-Aleutian megathrust. We numerically model tsunamis generated by three different megathrust earthquakes, analyze tsunami wave dynamics, and develop approximate tsunami hazard maps for the communities. The hypothetical tsunami scenarios examined simulate $\mathrm{M}_{\mathrm{W}} 9.0$ megathrust earthquakes with a slip distribution in the 5-54 km (3-33 mi) depth range along the Alaska-Aleutian megathrust. The maximum runup heights are $13 \mathrm{~m}$ (42 $\mathrm{ft}$ ) in False Pass and $21 \mathrm{~m}$ (69 ft) in Perryville. Results presented here are intended to provide guidance to local emergency management agencies in initial tsunami inundation assessment, evacuation planning, and public education for mitigation of future tsunami hazards.
\end{abstract}

\section{INTRODUCTION}

Tsunami hazards along Alaska’s Pacific coastline are high. Virtually all of Alaska's southern and southeastern coasts are defined by major offshore fault systems. Unlike tsunamis that are caused by distant earthquakes on the other side of the Pacific, Alaska's greatest tsunami hazards originate just offshore and can inundate coastlines within an hour of a causative earthquake. This reduces the time available to respond and evacuate, and can produce drastically higher wave heights than far-traveled tsunamis. Because many Alaska communities hug the shoreline (due to some combination of steep mountains, dense forests, and/or reliance on the open water for transportation), many Alaska communities are within the tsunami inundation zone and are at risk of rapid flooding. In addition to earthquake-generated (i.e., tectonic) tsunamis, mass movements of sediments down slopes (either on land or in the ocean) can also generate tsunamis. While rapid tsunami flooding is the immediate concern after a large coastal earthquake, dangerous near-shore ocean currents and permanent changes to the local coastline are additional concerns.

The local, tectonic tsunami danger to communities on the Alaska Peninsula and in the Aleutian Islands comes primarily from the Alaska-Aleutian subduction zone (fig. 1). This subduction zone marks the boundary between the Pacific plate to the south and the North American plate to the north. Relative to the North American plate, the Pacific Plate is moving northwest at approximately $5-8 \mathrm{~cm}$ (2-3 inches) per year, colliding with the North American plate and diving beneath it in a process known as subduction. The latest sequence of large megathrust earthquakes began in 1938

\footnotetext{
${ }^{1}$ Alaska Earthquake Center, Geophysical Institute, University of Alaska, P.O. Box 757320, Fairbanks, Alaska 99775-7320; ensuleimani@alaska.edu

${ }^{2}$ Alaska Division of Geological \& Geophysical Surveys, 3354 College Rd., Fairbanks, Alaska 99709-3707.

${ }^{3}$ Nevada Bureau of Mines and Geology, Mackay School of Earth Science and Engineering, University of Nevada, Reno, 1664 North Virginia Street, MS 178, Reno, NV 89557
} 


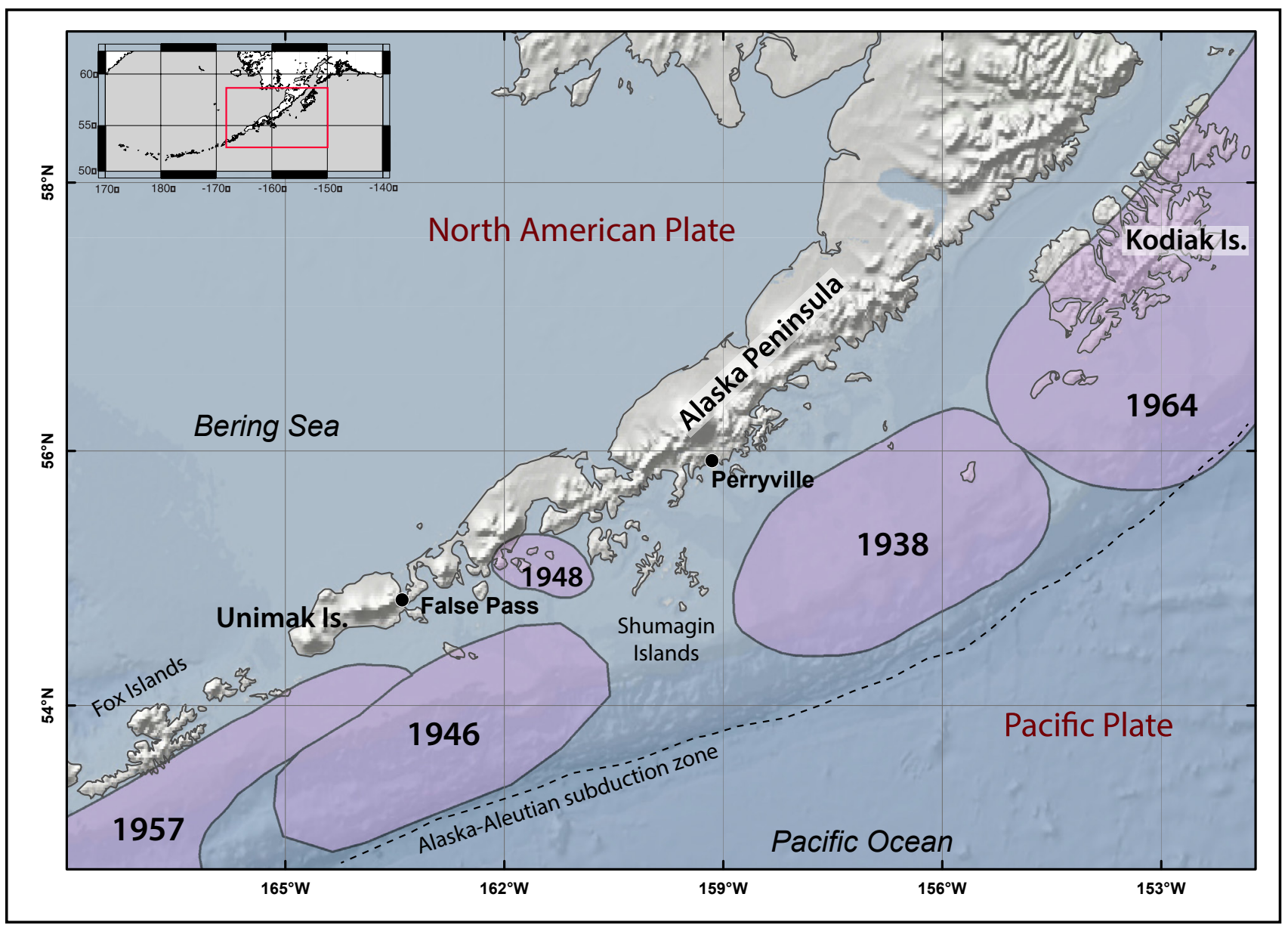

Figure 1. Map of the western Alaska Peninsula and eastern Aleutian Islands, showing the locations of the communities of False Pass and Perryville. The rupture areas in the latest sequence of great and large earthquakes are shown by shaded ovals.

with a $\mathrm{M}_{\mathrm{w}} 8.3$ earthquake west of Kodiak Island (Estabrook and others, 1994). Four subsequent events, the $1946 \mathrm{M}_{\mathrm{w}} 8.6$ Aleutian (Lopez and Okal, 2006), $1957 \mathrm{M}_{\mathrm{w}} 8.6$ Andreanof Islands (Johnson and others, 1994), $1964 \mathrm{M}_{\mathrm{W}} 9.2$ Alaska (Kanamori, 1970), and $1965 \mathrm{M}_{\mathrm{W}} 8.7$ Rat Island (Wu and Kanamori, 1973; not pictured) earthquakes, ruptured almost the entire length of the megathrust. Tsunamis generated by these great earthquakes reached Alaska coastal communities within minutes and resulted in widespread damage and loss of life (National Geophysical Database Center/World Data Service [NGDC/WDS]).

The specifics of tsunami hazards are particular to each community and vary considerably over large regions. The shape of the coastline, local bathymetry, and topography all affect tsunami impacts. More importantly, however, is the earthquake source (the location, size, and style) being considered and the community's location relative to that earthquake.

The impacts of future earthquakes and tsunamis can be reduced if citizens, emergency managers, and city planners take steps to mitigate the hazards. This report is intended to support hazard mitigation efforts by providing approximate tsunami hazard estimates for False Pass and Perryville. The scenario earthquakes, numerical tsunami models, and resulting maps are developed on a regional level and lack the precision of studies that are fully tailored to individual communities (e.g., Nicolsky and others, 2013; Nicolsky and others, 2014; Suleimani and others, 2013; 2015). The current study does not include sensitivity tests 
and is based on three scenario earthquakes. Even so, the results provide a good first approximation of tsunami hazard. The maps, documentation, and available digital data provide a foundation for public education, support the development of evacuation procedures, and provide insights intended to improve community resilience.

\section{PROJECT BACKGROUND: REGIONAL AND HISTORICAL CONTEXT \\ Community Profiles}

False Pass $\left(54^{\circ} 49^{\prime} 40^{\prime \prime} \mathrm{N}, \quad 163^{\circ} 23^{\prime} 57^{\prime \prime} \mathrm{W}\right)$, population 60 , is on the eastern end of Unimak Island on a strait that connects the Pacific Ocean to the Bering Sea; another part of the community is across the strait on the westernmost tip of the Alaska Peninsula (fig. 1). False Pass is $1,040 \mathrm{~km}$ (646 mi) southwest of Anchorage and $322 \mathrm{~km}(200$ mi) east of Dutch Harbor. According to the Alaska Department of Commerce, Community and Economic Development's Division of Community and Regional Affairs (DCCED/DCRA, 2013), the area was originally settled by a homesteader in the early 1900s, and the first cannery was established in 1917. Alaska Natives relocated to False Pass when the cannery was built. The cannery operated almost continuously until it was destroyed by fire in 1981. The city was incorporated in 1990. False Pass is a federally recognized tribe, primarily Unangan. Fishing, fish processing, and subsistence activities are major parts of the lifestyle. Boat and aircraft are the only ways to get to False Pass.

Perryville (5554'49"N, $\left.159^{\circ} 09^{\prime} 04^{\prime \prime W}\right)$, population 113, is on the southern coast of the Alaska Peninsula (fig. 1). It is $805 \mathrm{~km}(500 \mathrm{mi})$ southwest of Anchorage, and $443 \mathrm{~km}$ (275 mi) southwest of Kodiak. Perryville is an Alutiiq community and a federally recognized tribe, and maintains a subsistence lifestyle. Commercial fishing provides cash income. According to DCCED (2013), the community was founded in 1912 as a refuge for Alutiiq people driven away from their villages by the eruption at Mount Katmai. Captain Perry of the ship "Manning" transported people from the Katmai area to Ivanof Bay and later to the new village site. The village was originally called "Perry", but the "ville" was added to conform to the name of the area's post office, established in 1930. Perryville is only accessible by boat and aircraft. Scheduled and charter flights are available from King Salmon.

\section{Seismic and Tsunami History}

Perryville and False Pass are on opposite ends of the Shumagin Islands archipelago, a region comprised of -20 small islands where the rate of plate convergence is approximately $63-66 \mathrm{~mm}$ (2.5-2.6 in) per year (fig. 1; DeMets and others, 1990; Page and others, 1991; Argus and others, 2010). The Alaska-Aleutian megathrust beneath the Alaska Peninsula region has produced significant tsunamigenic earthquakes in the past. Refer to "Seismic and Tsunami History" in Nicolsky and others (2017) for a detailed description of these events and a summary of the tectonic regime of the western Alaska Peninsula.

According to the National Centers for Environmental Information (NCEI; formerly known as National Geophysical Database Center [NGDC]) Global Historical Tsunami Database (doi.org/10.7289/V5PN93H7) and Lander (1996), both False Pass and Perryville have been affected by historical tsunamis (table 1). On April 1, 1946, a $\mathrm{M}_{\mathrm{W}} 8.6$ earthquake near Unimak Island triggered a major destructive tsunami in the Pacific Ocean (Lopez and Okal, 2006). Local waves reached $42 \mathrm{~m}$ (138 ft) on Unimak Island and $3 \mathrm{~m}(10 \mathrm{ft})$ in Perryville. The Great Alaska Earthquake of March 27, 1964, resulted in some damage at the False Pass cannery. Other earthquakes and tsunamis likely affected the areas around False Pass and Perryville in the past; however, no records of events prior to 1946 are available.

\section{METHODOLOGY AND DATA Methodology}

The regional tsunami hazard maps presented here are the product of collaborative efforts 
Table 1. Tsunami effects at False Pass and Perryville: data from the National Centers for Environmental Information (NCEl; formerly known as National Geophysical Data Center [NGDC]) Global Historical Tsunami Database (doi.org/10.7289/ V5PN93H7) and comments from Lander (1996).

\begin{tabular}{|c|c|c|c|c|}
\hline Date & Magnitude $\left(\mathrm{M}_{\mathbf{w}}\right)$ & Origin & $\begin{array}{c}\text { Maximum Water } \\
\text { Height }(m)\end{array}$ & Comments $^{a}$ \\
\hline \multicolumn{5}{|c|}{ False Pass } \\
\hline $04 / 01 / 1946$ & 8.6 & $\begin{array}{l}\text { Unimak Island, } \\
\text { Alaska }\end{array}$ & 42.0 & $\begin{array}{l}\text { Relatively light } \\
\text { damage at } \\
\text { the False Pass } \\
\text { cannery. Pilings } \\
\text { were scattered. }\end{array}$ \\
\hline \multicolumn{5}{|c|}{ Perryville } \\
\hline $03 / 27 / 1964$ & 9.2 & Gulf of Alaska & 3.0 & $\begin{array}{l}\text { Tsunami waves } \\
\text { affected the } \\
\text { area about } 4.5 \\
\text { hours after the } \\
\text { shock. Three or } \\
\text { four waves were } \\
\text { reported. }\end{array}$ \\
\hline
\end{tabular}

Lander, 1996

between state and federal agencies to assist coastal communities in Alaska with tsunami hazard assessment. In recent years, similar tsunami hazard studies have been published for other communities (Nicolsky and others, 2011; Nicolsky and others, 2013; Nicolsky and others, 2014; Suleimani and others, 2010; Suleimani and others, 2013, 2015). Because the currently-available DEMs for these southern Alaska communities are of insufficient quality for high-resolution modeling, we follow the National Tsunami Hazard Mitigation Program (NTHMP, 2010) guidelines for determining tsunami hazard zones for areas that have either low risk due to small population size and minimal infrastructure vulnerability, or do not have access to high-resolution tsunami inundation maps. The tsunami hazard maps for False Pass and Perryville are developed using the methodology described in detail in Suleimani and others (2018a). In short, for three scenario earthquakes, we modeled water dynamics from source to community and computed maximum tsunami wave heights using the highest resolution grids available (see table 2). Each model run covers 6 hours of post-earthquake tsunami propagation to account for all waves in the wave train, as well as secondary (reflected) wave interactions. At every location throughout the high-resolution grids, the maximum tsunami height from any of the three earthquakes is saved, and we use these maximum values to extrapolate wave heights on land in a new, "composite" map of maximum runup heights that can be expected from the earthquake scenarios.

\section{Computational Grids and Data Sources}

To develop a regional tsunami hazard map we use a series of nested computational grids. A nested grid allows for higher resolution in areas where it is needed without expending computer resources in areas where it is not. The bathymetric and topographic relief in each nested grid is based on DEMs developed at the National Centers for Environmental Information (NCEI) of the National Oceanic \& Atmospheric Administration (NOAA) in Boulder, 
Table 2. Nested grids used to compute propagation of tsunami waves generated in the Pacific Ocean to the communities of False Pass and Perryville. The fine-resolution grids are used to compute the inundation. Note that the grid resolution in meters is not uniform and is used to illustrate grid fineness in the region of the western Alaska Peninsula. The first dimension is the longitudinal grid resolution; the second is the latitudinal resolution.

\begin{tabular}{|c|c|c|c|c|}
\hline \multirow[b]{2}{*}{ Grid name } & \multicolumn{2}{|c|}{ Resolution } & \multirow{2}{*}{$\begin{array}{l}\text { West-East } \\
\text { boundaries }\end{array}$} & \multirow{2}{*}{$\begin{array}{l}\text { South-North } \\
\text { boundaries }\end{array}$} \\
\hline & $\begin{array}{l}\text { arc-sec- } \\
\text { onds }\end{array}$ & $\begin{array}{l}\text { Meters (near } \\
\text { False Pass) }\end{array}$ & & \\
\hline Level 0, Northern Pacific & $120 \times 120$ & $\approx 1,850 \times 3,700$ & $\begin{array}{l}120^{\circ} 00^{\prime} \mathrm{E}- \\
100^{\circ} 00^{\prime} \mathrm{W}\end{array}$ & $\begin{array}{l}10^{\circ} 00^{\prime} \mathrm{N}- \\
65^{\circ} 00^{\prime} \mathrm{N}\end{array}$ \\
\hline Level 1, Eastern Aleutians & $24 \times 24$ & $\approx 430 \times 740$ & $\begin{array}{l}171^{\circ} 58^{\prime} \mathrm{W}- \\
157^{\circ} 02^{\prime} \mathrm{W}\end{array}$ & $\begin{array}{l}52^{\circ} 00^{\prime} \mathrm{N}- \\
57^{\circ} 28^{\prime} \mathrm{N}\end{array}$ \\
\hline $\begin{array}{l}\text { Level 2, Coarse resolution, } \\
\text { False Pass }\end{array}$ & $8 \times 8$ & $\approx 150 \times 250$ & $\begin{array}{l}161^{\circ} 47^{\prime} 44^{\prime \prime} \mathrm{W}- \\
163^{\circ} 48^{\prime} 42^{\prime \prime} \mathrm{W}\end{array}$ & $\begin{array}{l}54^{\circ} 14^{\prime} 35^{\prime \prime} \mathrm{N}- \\
55^{\circ} 30^{\prime} 14^{\prime \prime} \mathrm{N}\end{array}$ \\
\hline $\begin{array}{l}\text { Level 2, Coarse resolution, } \\
\text { Perryville }\end{array}$ & $8 \times 8$ & $\approx 150 \times 250$ & $\begin{array}{l}157^{\circ} 29^{\prime} 20^{\prime \prime} \mathrm{W}- \\
161^{\circ} 31^{\prime} 16^{\prime \prime} \mathrm{W}\end{array}$ & $\begin{array}{l}54^{\circ} 35^{\prime} 51^{\prime \prime} \mathrm{N}- \\
56^{\circ} 37^{\prime} 12^{\prime \prime} \mathrm{N}\end{array}$ \\
\hline $\begin{array}{l}\text { Level 3, Fine-resolution, } \\
\text { False Pass }\end{array}$ & $8 / 3 \times 8 / 3$ & $\approx 48 \times 82$ & $\begin{array}{l}162^{\circ} 50^{\prime} 51^{\prime \prime} \mathrm{W}- \\
163^{\circ} 28^{\prime} 45^{\prime \prime} \mathrm{W}\end{array}$ & $\begin{array}{l}54^{\circ} 37^{\prime} \mathrm{N}- \\
54^{\circ} 58^{\prime} 56^{\prime \prime} \mathrm{N}\end{array}$ \\
\hline $\begin{array}{l}\text { Level 3, Fine-resolution, } \\
\text { Perryville }\end{array}$ & $8 / 3 \times 8 / 3$ & $\approx 48 \times 82$ & $\begin{array}{l}157^{\circ} 58^{\prime} 40^{\prime \prime} \mathrm{W}- \\
159^{\circ} 35^{\prime} 34^{\prime \prime} \mathrm{W}\end{array}$ & $\begin{array}{l}55^{\circ} 30^{\prime} 58^{\prime \prime} \mathrm{N}- \\
56^{\circ} 26^{\prime} 28^{\prime \prime} \mathrm{N}\end{array}$ \\
\hline
\end{tabular}

Colorado. The extent of each grid used for the False Pass and Perryville mapping project is shown in figure 2 and listed in table 2 . The coarsest grid, level 0 , with 2-arc-minute (approximately $2 \mathrm{~km}$ ) resolution, spans the central and northern Pacific Ocean. The bathymetric data for the 2-arc-minute-resolution grid is extracted from the ETOPO2 dataset (NCEI/NOAA, doi.org/10.7289/V5J1012Q). We use two intermediate grids between the coarsest- and highest-resolution grids (table 2). The first intermediate grid of 24 arc-second resolution (level 1) was developed to accommodate the current tsunami mapping project for False Pass and Perryville as well as other tsunami mapping efforts for communities located in the Fox Islands, St. Paul Island, and St. George Island (fig. 2). The data sources and methodology used to develop the 24-arc-second DEMs are described in detail by Lim and others (2011). The 8-, and 8/3-arc-second
DEMs were developed by the National Oceanic and Atmospheric Administration's NCEI in the scope of NTHMP (Jason Caldwell, oral communication).

The spatial resolution of the fine-resolution grid cells, about $48 \times 82 \mathrm{~m}(157 \times 269 \mathrm{ft})$, satisfies NOAA minimum recommended requirements for estimation of the tsunami hazard zone (National Tsunami Hazard Mapping Program [NTHMP], 2010); however, no DEM verification efforts were conducted to reduce uncertainties in the high-resolution, level 3, False Pass and Perryville grids. Therefore, in this report we do not perform high-resolution runup modeling, but provide an estimation of the tsunami hazard zone by extrapolating the maximum composite tsunami wave height on land according to the tsunami scenarios described below. We account for uncertainties inherent to this method by applying a safety factor 


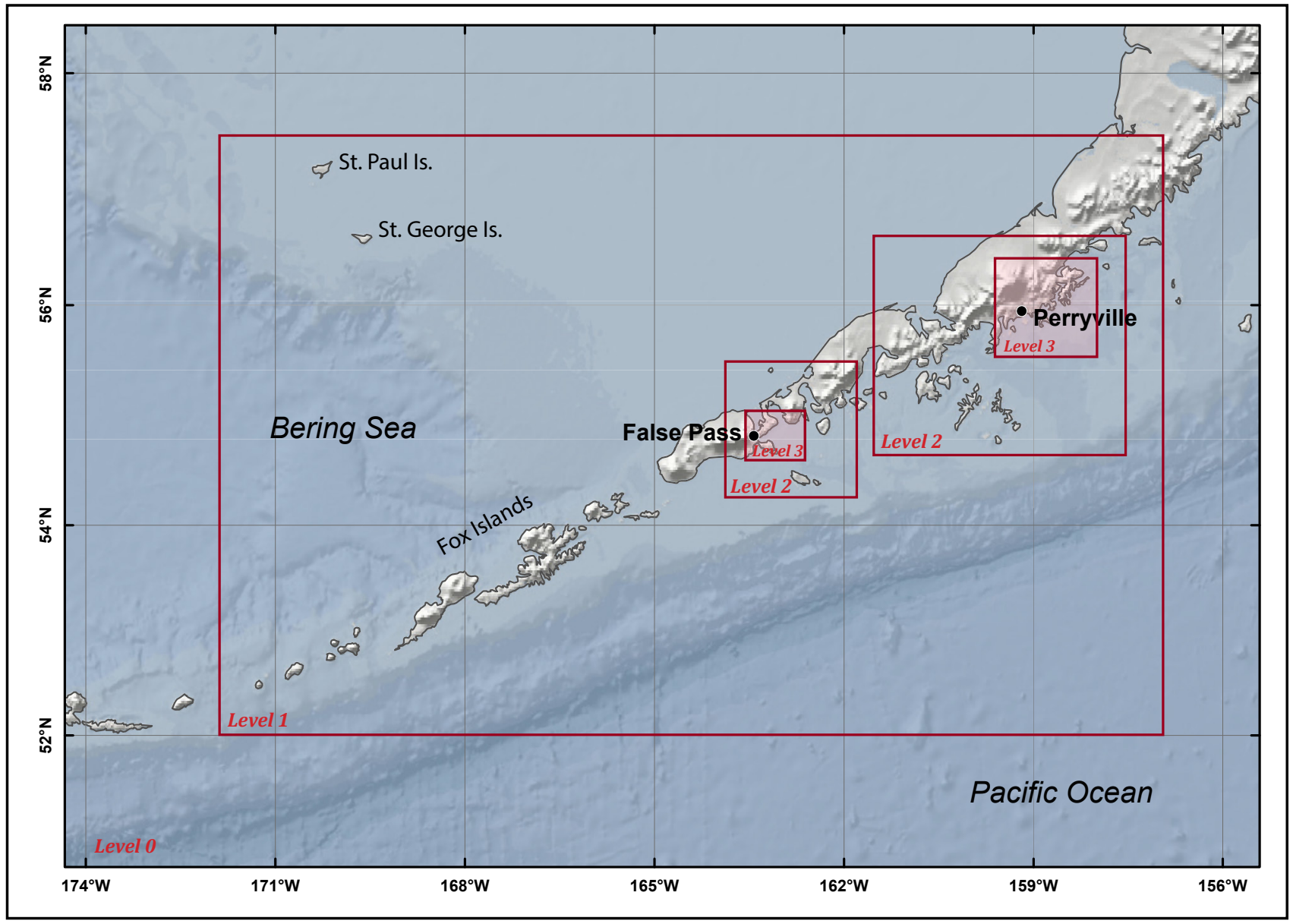

Figure 2. Nested bathymetry/topography grids for numerical modeling of tsunami propagation and runup. The coarsest grid, level 0, covers the central and northern Pacific Ocean. The location of each embedded grid is marked by a red rectangle. Refer to table 2 for grid parameters.

of 1.3 (Suleimani and others, 2018a) to the estimated hazard zone.

\section{Tsunami Sources}

In this project we use a deterministic approach to develop potential tsunami sources, which is distinctly different from the probabilistic hazard analyses used in projects with different objectives, such as land-use planning or insurance estimates (Geist and Parsons, 2006). Alaska tsunami hazard maps are produced on the basis of significant credible tsunamigenic earthquake scenarios for a given segment of the coastline. Although we do not explicitly develop worst-case tsunami scenarios for False Pass and Perryville, we use the underlying assumptions and results from previous high-resolution tsunami mapping studies (see for example,
Nicolsky and others, 2017) regarding the maximum considered earthquake scenarios for other locations along the Alaska-Aleutian subduction zone.

In this regional tsunami hazard assessment we consider three characteristic tsunamigenic earthquake scenarios (e.g., Suleimani and others, 2018a). These potential megathrust ruptures have a uniform slip distribution along strike, but differ in the downdip slip distribution pattern such that the depth range at which the maximum slip occurs varies from the shallow region close to the trench to the deeper parts of the plate interface. All ruptures have the same lateral extent, which is determined by the location of communities and constrained by maximum seismic moment. Refer to Suleimani and others (2018a) for a description 
of the scenario development and for the proposed slip distributions.

The three characteristic tsunami scenarios for False Pass and Perryville are outlined below. The vertical coseismic deformations for these scenarios are shown in figure 3. The main rupture parameters and amount of permanent subsidence in the communities are listed in table 3 .

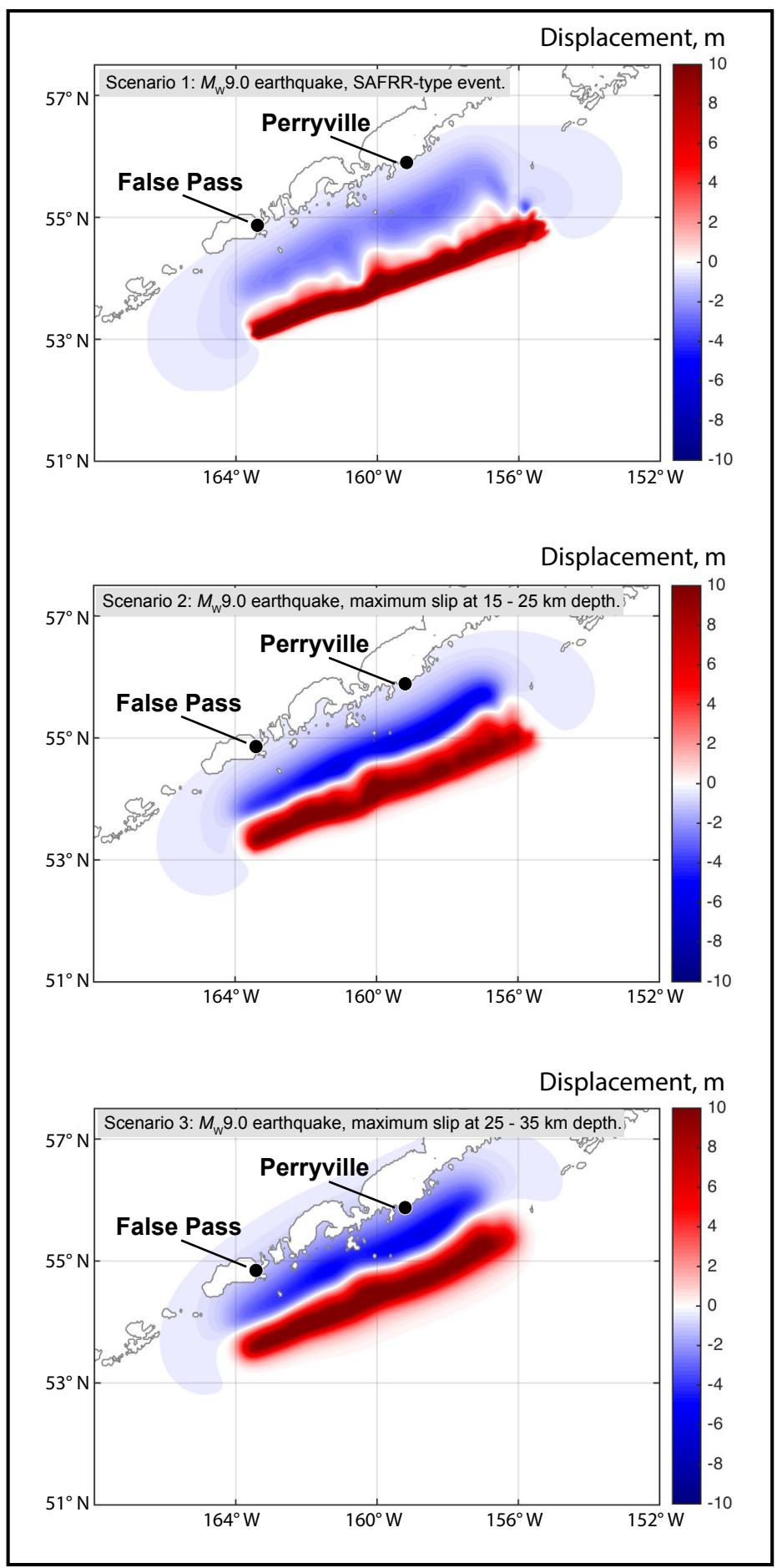

Figure 3. Vertical coseismic deformations corresponding to scenarios 1-3. Blue areas are associated with coseismic ground subsidence; areas of uplift are shown in red. 
Table 3. Significant credible tsunami sources for False Pass and Perryville. "Actual subsidence" is the subsidence that the model shows for the community, which may be (significantly) less than the maximum expected subsidence across the entire region for that same earthquake scenario.

\begin{tabular}{|c|c|c|c|c|c|c|c|c|}
\hline & Scenarios & $\begin{array}{l}\text { Depth } \\
\text { range, } \\
\text { km (mi) }\end{array}$ & $\begin{array}{l}\text { Maxi- } \\
\text { mum slip } \\
\text { depth } \\
\text { range, } \\
\text { km (mi) }\end{array}$ & $\begin{array}{l}\text { Maximum } \\
\text { slip, m (ft) }\end{array}$ & $\begin{array}{l}\text { Maximum } \\
\text { regional } \\
\text { subsid- } \\
\text { ence, } \\
\text { m (ft) }\end{array}$ & $\begin{array}{l}\text { Maximum } \\
\text { regional } \\
\text { uplift, } \\
\text { m(ft) }\end{array}$ & $\begin{array}{l}\text { Actual } \\
\text { subsid- } \\
\text { ence in } \\
\text { False } \\
\text { Pass, } \\
m(f t)\end{array}$ & $\begin{array}{c}\text { Actual } \\
\text { subsid- } \\
\text { ence in } \\
\text { Perryville, } \\
\text { m (ft) }\end{array}$ \\
\hline 1 & $\begin{array}{l}\mathrm{M}_{\mathrm{w}} 9.0 \\
\text { earthquake: } \\
\text { SAFRR-type } \\
\text { event, slip near } \\
\text { the trench }\end{array}$ & $\begin{array}{c}8-54 \\
(5-33)\end{array}$ & $\begin{array}{c}11-14 \\
(7-8.5)\end{array}$ & $\begin{array}{c}55-65 \\
(180-213)\end{array}$ & $-3.4(-11.2)$ & $14.7(48.2)$ & $\begin{array}{l}-0.2 \\
(-0.7)\end{array}$ & $\begin{array}{c}-0.4 \\
(-1.3)\end{array}$ \\
\hline 2 & $\begin{array}{l}\mathrm{M}_{\mathrm{W}} 9.0 \\
\text { earthquake: } \\
\text { Maximum slip } \\
\text { at } 15-25 \mathrm{~km} \\
\text { (9.3-15.5 mi) } \\
\text { depth }\end{array}$ & $\begin{array}{c}5-35 \\
(3-21.7)\end{array}$ & $\begin{array}{c}15-25 \\
(9.3-15.5)\end{array}$ & $\begin{array}{c}34-35 \\
(111-115)\end{array}$ & $-6.3(-20.7)$ & $13.2(43.3)$ & $\begin{array}{l}-0.3 \\
(-1.0)\end{array}$ & $\begin{array}{c}-0.5 \\
(-1.6)\end{array}$ \\
\hline 3 & $\begin{array}{l}\mathrm{M}_{\mathrm{W}} 9.0 \\
\text { earthquake: } \\
\text { Maximum slip } \\
\text { at } 25-35 \mathrm{~km} \\
\text { (15.5-21.7 mi) } \\
\text { depth }\end{array}$ & $\begin{array}{l}14-45 \\
(8-26)\end{array}$ & $\begin{array}{c}25-35 \\
(15.5-21.7)\end{array}$ & $\begin{array}{c}34-35(111- \\
115)\end{array}$ & $-5.7(-18.7)$ & $12.6(41.3)$ & $\begin{array}{l}-1.1 \\
(-3.6)\end{array}$ & $\begin{array}{l}-2.0 \\
(-6.6)\end{array}$ \\
\hline
\end{tabular}

Scenario 1. $M_{w} 9.0$ earthquake: SAFRR-type

event
A hypothetical $\mathrm{M}_{\mathrm{W}} 9.0$ earthquake rupturing the AlaskaAleutian megathrust. During the 2011 Tohoku earthquake a large amount of slip occurred in a shallow region between the subducting and overriding plates near the Japan trench (Fujii and others, 2011; Shao and others, 2011). The USGS Science Application for Risk Reduction (SAFRR) project, in collaboration with NOAA and State of California agencies, has developed a plausible hypothetical tsunami scenario (Kirby and others, 2013) to describe the impacts of a tsunami generated by an earthquake in the Alaska Peninsula region (Ross and others, 2013). Here we assume that the slip distribution in the downdip direction is the same as that in the SAFRR source, where greater slip occurs close to the trench. This hypothetical rupture is positioned across the undersea shelf from False Pass and Perryville. The slip is distributed almost uniformly along strike except for the edges of the rupture, where it tapers. The maximum slip of $46 \mathrm{~m}(151 \mathrm{ft})$ is at a depth of 5-15 km (3-9 mi). Vertical coseismic deformations for this scenario are shown in figure $3 a$. 
Scenario 2. $M_{w} 9.0$ earthquake: Maximum slip at 15-25 km (9-15 mi) depth

Scenario 3. $M_{W} 9.0$ earthquake: Maximum slip at 25-35 km (15-22 mi) depth
A hypothetical $M_{W} 9.0$ earthquake rupturing the Alaska-Aleutian megathrust. The slip is distributed almost uniformly along strike except for the edges of the rupture, where it tapers. The maximum slip of $35 \mathrm{~m}(115 \mathrm{ft})$ is at a depth of $15-25 \mathrm{~km}$ (9-15 mi). Vertical coseismic deformations for this scenario are shown in figure $3 \mathrm{~b}$.

A hypothetical $M_{w} 9.0$ earthquake rupturing the Alaska-Aleutian megathrust. The slip is distributed almost uniformly along strike except for the edges of the rupture, where it tapers. The maximum slip of $35 \mathrm{~m}(115 \mathrm{ft})$ is at a depth of $25-35 \mathrm{~km}$ (15-22 mi). Vertical coseismic deformations for this scenario are shown in figure $3 \mathrm{c}$.

\section{Numerical Model of Tsunami Propagation and Runup}

The numerical model currently used by the Alaska Earthquake Center (AEC) for tsunami inundation mapping is a nonlinear, flux-formulated, shallow-water model (Nicolsky and others, 2011) that has been validated (NTHMP, 2012) through a set of analytical benchmarks and tested against laboratory and field data (Synolakis and others, 2007). The application of the model to tsunami inundation mapping of Alaska's coastal communities, including its assumptions and limitations, is described in a number of previous tsunami reports (for example, Suleimani and others, 2018b). In this study we conduct all model runs using bathymetric data that correspond to the Mean Higher High Water (MHHW) tide level in False Pass and Perryville.

For each tsunami scenario, we first calculate the maximum tsunami wave heights in the highest-resolution grid over the course of the entire model run in the following way: at each grid point, the tsunami wave height is computed at every time step during the tsunami propagation time and the maximum value is kept. Then we compute the composite maximum wave height from all considered scenarios by again choosing the maximum value for each grid point among all scenarios, and plot the results.

\section{MODELING RESULTS}

Figures 4 and 5 show the maximum tsunami heights for scenarios 1-3 in the False Pass and Perryville level 3 grids, respectively. In the False Pass area, all scenarios produce a similar energy pattern. The highest tsunami amplitudes are present along the south shore of the Ikatan Peninsula, which acts as a shelter for Ikatan Bay and False Pass. In the Perryville grid, scenarios 1 and 2 result in higher tsunami amplitudes along the coastline east of the community, while scenario 3 generates high-amplitude waves that are almost uniformly distributed along the southern coast of the Alaska Peninsula.

We show the maximum composite tsunami height (including inundated coastlines) for all scenarios calculated for the vicinity of False Pass in figure 6. The absolute maximum value of the tsunami height in this region is $10 \mathrm{~m}(32.8 \mathrm{ft})$; multiplied by a safety factor of 1.3 it predicts $13 \mathrm{~m}$ (42.7 $\mathrm{ft}$ ) for the maximum estimated runup height for False Pass. Figure 7 shows the maximum composite tsunami height for all scenarios calculated for the vicinity of Perryville. The absolute maximum value of the tsunami height in this region is $16 \mathrm{~m}(52.5$ $\mathrm{ft}$ ); multiplied by a safety factor of 1.3 it predicts $21 \mathrm{~m}(68.9 \mathrm{ft})$ for the maximum estimated runup height for the community of Perryville. 


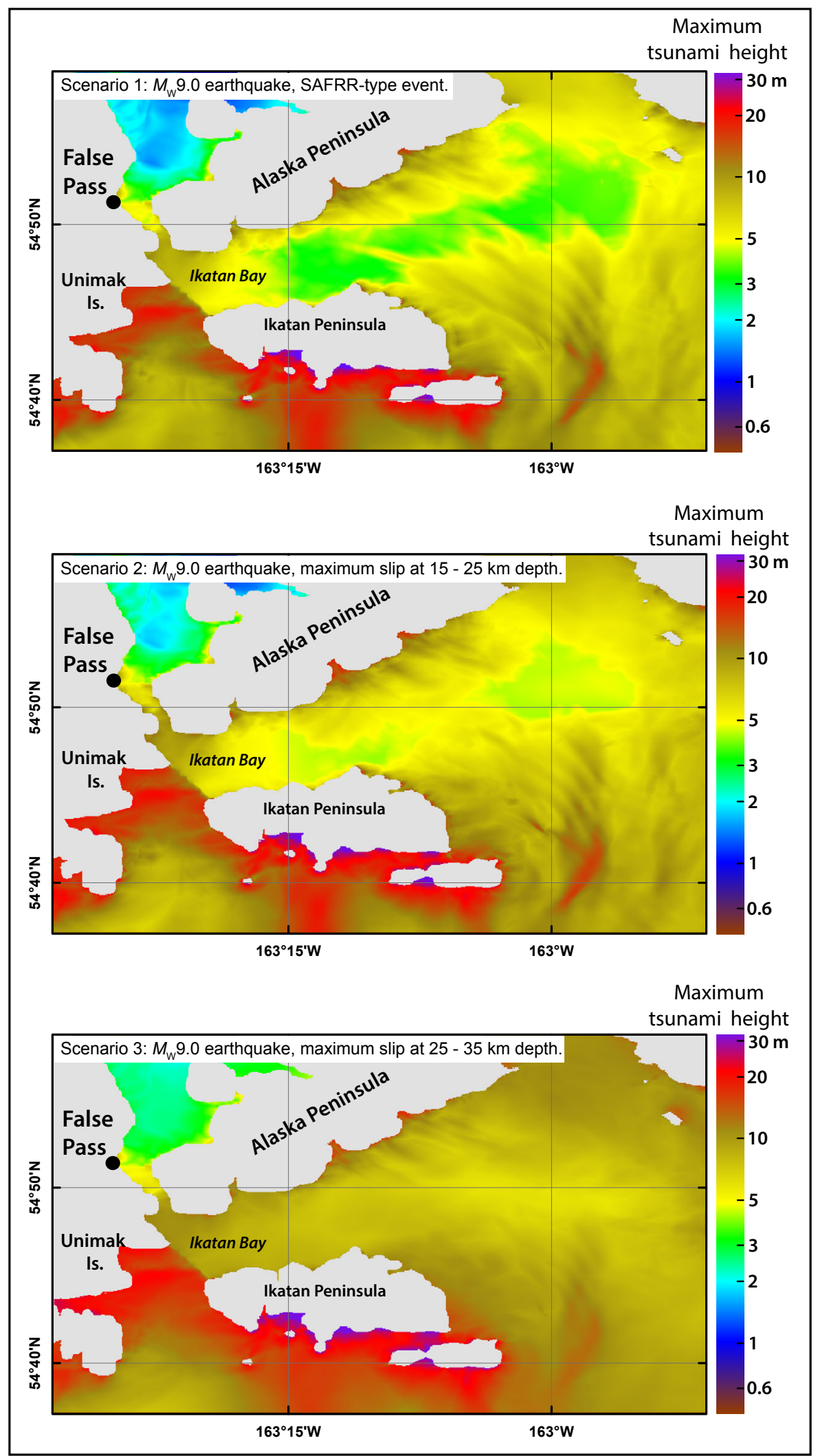

Figure 4. Maximum tsunami heights for scenarios 1-3 in the level 3 grid for False Pass. 


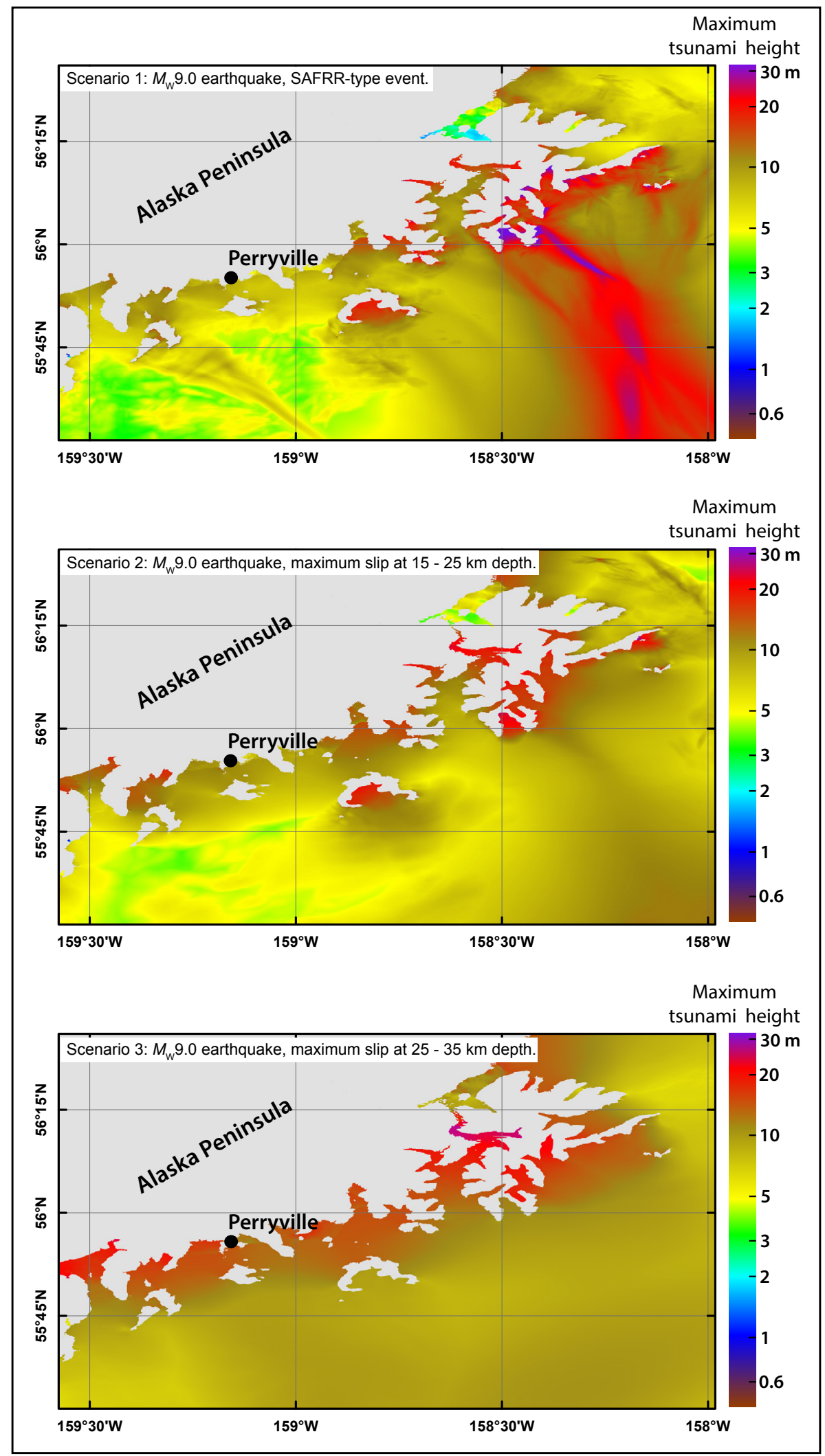

Figure 5. Maximum tsunami heights for scenarios 1-3 in the level 3 grid for Perryville. 
Map Sheets 1 and 2 illustrate approximate tsunami hazards for False Pass and Perryville, respectively, and indicate that most of the buildings and infrastructure in each community are within the potential tsunami inundation zone. For each community, we draw an elevation contour on the topographic map that corresponds to the maximum estimated runup height. This contour is the approximate boundary of the tsunami hazard zone, and should be used by emergency planners and public officials as a guideline in tsunami mitigation activities. We used the DCRA elevation datasets based on digital orthophotos of the communities. For False Pass, the closest contour to the maximum runup height of $13 \mathrm{~m}(42.7 \mathrm{ft})$ was at the elevation of $12.1 \mathrm{~m}(39.6 \mathrm{ft})$ and therefore was extracted as the tsunami hazard boundary. For Perryville, the closest DCRA contour to the maximum runup height of $21 \mathrm{~m}(68.9 \mathrm{ft})$ was at the elevation of $21 \mathrm{~m}(68.9 \mathrm{ft})$ and therefore was extracted as the tsunami hazard boundary. Refer to this report's accompanying metadata for more details.

To help emergency managers understand the duration of tsunami hazards after a large megathrust earthquake, we supplement the hazard maps with the time series of the modeled water level at a nearshore location. These locations are shown by black triangles in figures 6 and 7, and the time series plots are shown in figure 8. Zero time corresponds to the earthquake occurrence. To compare the height of arriving tsunamis for different scenarios that result in different values of land subsidence, we use a vertical datum with a zero mark corresponding to the post-earthquake sea level. Time series plots show that scenario 2 results in the highest waves at False Pass, and scenario 3 generates the highest waves at Perryville. Also, the time series plots demonstrate that dangerous waves may affect the communities for more than 6 hours.

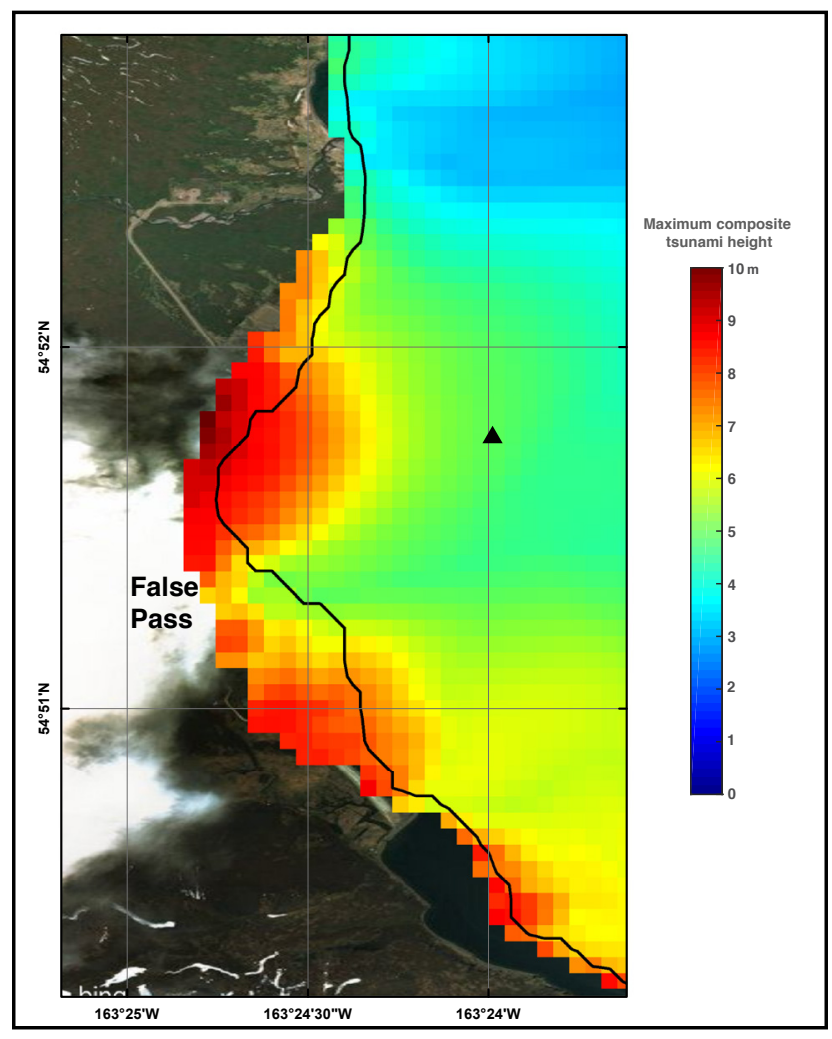

Figure 6. Maximum composite tsunami height for False Pass. The black triangle indicates the location of the time series point, and the black contour is the MHHW shoreline.
Figure 7. Maximum composite tsunami height for Perryville. The black triangle indicates the location of the time series point, and the black contour is the MHHW shoreline.

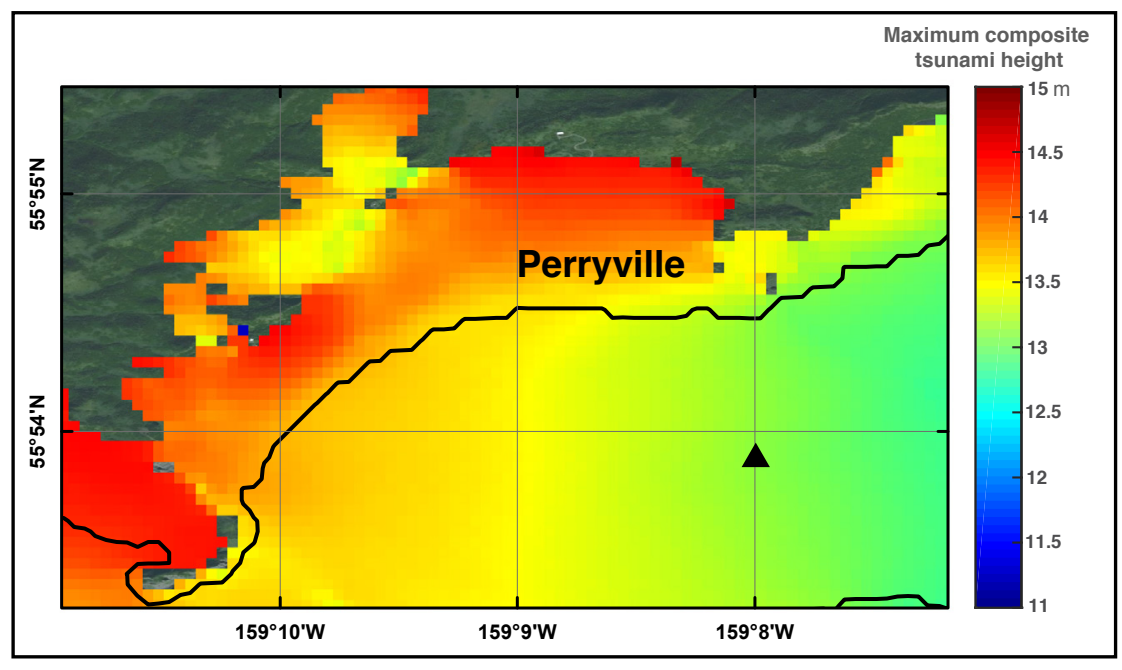




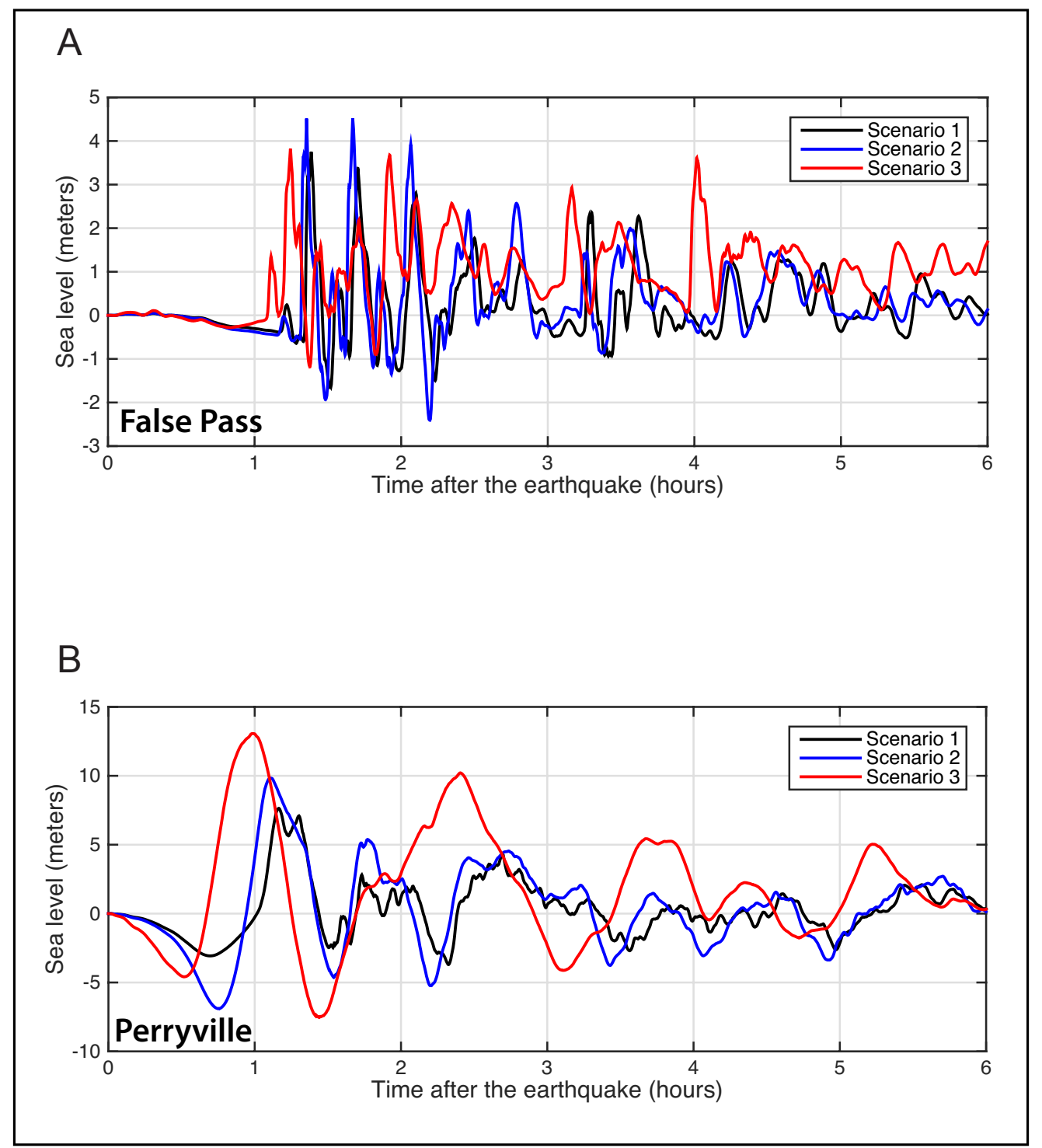

Figure 8. Time series of water level for scenarios 1-3 at (A) False Pass, and (B) Perryville, calculated at the locations shown by black triangles in figures 6 and 7.

In addition to the time series of the simulated water levels, we have also modeled the potential permanent subsidence in False Pass and Perryville. The yellow line in map sheets 1 and 2 shows the post-earthquake MHHW shoreline after ground subsidence. Scenario 3 results in maximum subsidence of $1 \mathrm{~m}(3.3 \mathrm{ft})$ in False Pass and $2 \mathrm{~m}(6.6 \mathrm{ft})$ in Perryville (table 3). Some low-lying areas in False Pass could be permanently flooded as a result of this hypothetical earthquake, while the permanently flooded area in Perryville includes only a narrow band of land along the shoreline.

\section{SUMMARY}

We numerically model tsunami waves generated by local hypothetical earthquake sources, analyze tsunami wave dynamics, and develop approximate tsunami hazard maps for False Pass and Perryville. Specifically, we compute the composite maximum wave height from all considered earthquakes and follow NTHMP guidelines to extrapolate the modeled wave heights on land for estimation of tsunami inundation. Maximum assumed runup heights that include a safety factor are $13 \mathrm{~m}(42.6 \mathrm{ft})$ and $21 \mathrm{~m}(68.9 \mathrm{ft})$ for False Pass and Perryville, respectively. 
Tsunami inundation approximations shown on the tsunami hazard maps have been completed using the best information available and are believed to be accurate; however, their preparation required many assumptions. In this assessment, we estimate the potential tsunami inundation zone based on three significant earthquakes. Although the modeled tsunami inundation cannot be considered exhaustive, modeling results are still thought to provide a sound approximation to the potential tsunami inundation zone in the communities. Note that actual conditions during a tsunami event may vary from those considered, so the accuracy cannot be guaranteed. The limits of inundation shown should be used only as a guideline for emergency planning and response action. Actual areas inundated will depend on specifics of earth deformation, land construction, and tide level, and may differ from areas shown on the maps. The information on the hazard maps is intended to assist state

\section{REFERENCES}

Alaska Department of Commerce, Community and Economic Development, Division of Community and Regional Affairs (DCCED/DCRA), 2013, False Pass community profile. dcra-cdo-dcced. opendata.arcgis.com/

Alaska Department of Commerce, Community and Economic Development, Division of Community and Regional Affairs (DCCED/DCRA), 2013, Perryville community profile, dcra-cdo-dcced. opendata.arcgis.com/

Argus, D.F., Gordon, R.G., Heflin, M.B., Ma, Chopo, Eanes, R.J., Willis, Pascal, Peltier, W.R., and Owen, S.E, 2010, The angular velocities of the plates and the velocity of the Earth's centre from space geodesy: GeophysicsJournalInternational,v.180,no.3,p.913960. doi.org/10.1111/j.1365-246X.2009.04463.x Don Argus kindly provided us with the GEODVEL NNR angular velocities.

DeMets, Charles, Gordon, R.C., Argus, D.F., and Stein, Seth, 1990, Current plate motions: Geophysical Journal International, v. 101, no. 2, p. 425-478. doi.org/10.1111/j.1365246X.1990.tb06579.x and local agencies in planning emergency evacuation and tsunami response actions in the event of a major tsunamigenic earthquake. These results are not intended for land-use regulation or building-code development.

\section{ACKNOWLEDGMENTS}

This project, which is part of the National Tsunami Hazard Mitigation Program (NTHMP), received support from the National Oceanic and Atmospheric Administration (NOAA) under Reimbursable Services Agreement ADN 952011 with the State of Alaska's Division of Homeland Security \& Emergency Management (a division of the Alaska Department of Military and Veterans Affairs). Numerical calculations for this work were supported by a grant of High Performance Computing (HPC) resources from the Arctic Region Supercomputing Center (ARSC) at the University of Alaska Fairbanks.

Estabrook, C.H., Jacob, K.H., and Sykes, L.R., 1994, Body wave and surface wave analysis of large and great earthquakes along the eastern Aleutian arc, 1923-1993-Implications for future events: Journal of Geophysical Research, v. 99, no. B6, p. 11,643-11,662. doi.org/10.1029/93JB03124

Fujii, Yushiro, Satake, Kenji, Sakai, Shin'ichi, Shinohara, Masanao, and Kanazawa, Toshihiko, 2011, Tsunami source of the 2011 off the Pacific coast of Tohoku earthquake: Earth Planets Space, v. 63, p. 815-820. doi.org/10.5047/ eps.2011.06.010

Geist, L.G., and Parsons, Tom, 2006, Probabilistic analysis of tsunami hazards: Natural Hazards, v. 37, no. 3, p. 277-314. doi.org/10.1007/s11069005-4646-z

Johnson, J.M., Tanioka, Yuichiro, Ruff, L.J., Satake, Kenji, Kanamori, Hiroo, and Sykes, L.R., 1994, The 1957 great Aleutian earthquake: Pure and Applied Geophysics, v. 142, no. 1, p. 3-28. doi.org/10.1007/BF00875966

Kanamori, Hiroo, 1970, The Alaska earthquake of 1964-Radiation of long-period surface waves and source mechanism: Journal of Geophysical 
Research, v. 75, no. 26, p. 5,029-5,040. doi.org/10.1029/JB075i026p05029

Kirby, Stephen, Scholl, David, von Huene, Roland, and Wells, Ray, 2013, Alaska earthquake source for the SAFRR tsunami scenario, chapter B, in Ross, S.L., and Jones, L.M., eds., The SAFRR (Science Application for Risk Reduction) Tsunami Scenario: U.S. Geological Survey Open-File Report 20131170, 40 p. pubs.usgs.gov/of/2013/1170/b/

Lander, J.F., 1996, Tsunamis affecting Alaska, 1737-1996: Boulder, CO, National Oceanic and Atmospheric Administration (NOAA), National Geophysical Data Center (NGDC), Key to Geophysical Research Documentation, v. 31, $155 \mathrm{p}$.

Lim, E., Eakins, B.W., and Wigley, R., 2011, Coastal relief model of southern Alaska-Procedures, data sources and analysis: National Oceanic and Atmospheric Administration (NOAA) Technical Memorandum NESDIS NGDC-43, 22 p.

Lopez, A.M., and Okal, E.A., 2006, A seismological reassessment of the source of the 1946 Aleutian 'tsunami' earthquake: Geophysical Journal International, v. 165 , no. 3, p. 835-849. doi.org/10.1111/j.1365-246X.2006.02899.x

National Geophysical Data Center (NGDC), 2006, 2-minute Gridded Global Relief Data (ETOPO2) v2: National Geophysical Data Center (NGDC), National Oceanic and Atmospheric Administration (NOAA). doi. org/10.7289/V5J1012Q

National Geophysical Data Center/World Data Service (NGDC/WDS), continuously updated, Global historical tsunami database at NGDC, $2100 \mathrm{BC}$ to present (interactive map): National Oceanic and Atmospheric Administration (NOAA), National Geophysical Data Center (NGDC). doi.org/10.7289/V5PN93H7

National Tsunami Hazard Mapping Program (NTHMP), 2010, Guidelines and best practices for tsunami inundation modeling for evacuation planning: National Oceanic and Atmospheric Administration (NOAA), NTHMP Mapping \& Modeling Subcommittee. nws.weather.gov/nthmp/ documents/1inundationmodelingguidelines.pdf 2012, Proceedings and results of the 2011 NTHMP Model Benchmarking Workshop:
Boulder, CO, U.S. Department of Commerce/ NOAA/NTHMP, NOAA Special Report, 436 p.

Nicolsky, D.J., Suleimani, E.N., Combellick, R.A., and Hansen, R.A., 2011, Tsunami inundation maps of Whittier and western Passage Canal, Alaska: Alaska Division of Geological \& Geophysical Surveys Report of Investigation 2011-7, 65 p. doi.org/10.14509/23244

Nicolsky, D.J., Suleimani, E.N., Haeussler, P.J., Ryan, H.F., Koehler, R.D., Combellick, R.A., and Hansen, R.A., 2013, Tsunami inundation maps of Port Valdez, Alaska: Alaska Division of Geological \& Geophysical Surveys Report of Investigation 2013-1, 77 p., 1 sheet, scale 1:12,500. doi.org/10.14509/25055

Nicolsky, D.J., Suleimani, E.N., and Koehler, R.D., 2014, Tsunami inundation maps of Cordova and Tatitlek, Alaska: Alaska Division of Geological \& Geophysical Surveys Report of Investigation 2014-1, 49 p. doi.org/10.14509/27241

Nicolsky, D.J., Suleimani, E.N., and Koehler, R.D., 2017, Tsunami inundation maps for the city of Sand Point, Alaska: Alaska Division of Geological \& Geophysical Surveys Report of Investigation 2017-3, 61 p., 4 sheets, scale 1:15,000. doi.org/10.14509/29706

Page, R.A., Biswas, N.N., Lahr, J.C., and Pulpan, Hans, 1991, Seismicity of continental Alaska, in Slemmons, D.B., Engdahl, E.R., Zoback, M.D., and Blackwell, D.D., eds., Neotectonics of North America: Boulder, Colorado, Geological Society of America, Decade Map v. 1, p. 47-68. Ross, S.L., Jones, L.M., Miller, Kevin, Porter, K.A., Wein, A., Wilson, R.I., Bahng, Bohyun, Barberopoulou, Aggeliki, Borrero, J.C., Brosnan, D.M., Bwarie, J.T., Geist, E.L., Johnson, L.A., Kirby, S.H., Knight, W.R., Long, Kate, Lynett, Patrick, Mortensen, C.E., Nicolsky, D.J., Perry, S.C., Plumlee, G.S., Real, C.R., Ryan, Kenneth, Suleimani, Elena, Thio, H.K., Titov, V.V., Whitmore, P.M., and Wood, N.J., 2013, SAFRR (Science Application for Risk Reduction) tsunami scenario-Chapter A, Executive summary and introduction, in Ross, S.L., and Jones, L.M., eds., The SAFRR tsunami scenario: U.S. Geological Survey Open-File Report 2013-1170, p. 1-17. pubs.usgs.gov/of/2013/1170/ 
Shao, Guangfu, Li, Xiangyu, Ji, Chen, and Maeda, Takahiro, 2011, Focal mechanism and slip history of $2011 \mathrm{M}_{\mathrm{w}} 9.1$ off the Pacific coast of Tohoku earthquake, constrained with teleseismic body and surface waves: Earth Planets Space, v. 63, no. 7, p. 559-564. doi.org/10.5047/eps.2011.06.028

Suleimani, E.N., Nicolsky, D.J., West, D.A., Combellick, R.A., and Hansen, R.A., 2010, Tsunami inundation maps of Seward and northern Resurrection Bay, Alaska: Alaska Division of Geological \& Geophysical Surveys Report of Investigation 2010-1, 47 p., 3 sheets, scale 1:12,500. doi.org/10.14509/21001

Suleimani, E.N., Nicolsky, D.J., and Koehler, R.D., 2013, Tsunami inundation maps of Sitka, Alaska: Alaska Division of Geological \& Geophysical Surveys Report of Investigation 2013-3, 76 p., 1 sheet, scale 1:12,500. doi.org/10.14509/26671

Suleimani, E.N., Nicolsky, D.J., and Koehler, R.D., 2015, Tsunami inundation maps of Elfin Cove, Gustavus, and Hoonah, Alaska: Alaska Division of Geological \& Geophysical Surveys Report of Investigation 2015-1, 79 p., 3 sheets. doi.org/10.14509/29404
Suleimani, E.N., Nicolsky, D.J., Koehler, R.D., and Salisbury, J.B., 2018a, Regional tsunami hazard assessment for Andreanof Islands, Alaska: Alaska Division of Geological \& Geophysical Surveys Report of Investigation 2017-2, 19 p., 2 sheets. doi.org/10.14509/29704

Suleimani, E.N., Nicolsky, D.J., and Salisbury, J.B., 2018b, Updated tsunami inundation maps for Homer and Seldovia, Alaska: Alaska Division of Geological \& Geophysical Surveys Report of Investigation 2018-5, 97 p., 4 sheets. doi. org/10.14509/30095

Synolakis, C.E., Bernard, E.N., Titov, V.V., Kânoğlu, U., and González, F.I., 2007, Standards, criteria, and procedures for NOAA evaluation of tsunami numerical models: Seattle, WA, NOAA/Pacific Marine Environmental Laboratory (PMEL), Technical Memorandum OAR PMEL-135, 55 p.

Wu, F.T., and Kanamori, Hiroo, 1973, Source mechanism of February 4, 1965, Rat Island earthquake: Journal of Geophysical Research, v. 78, no. 26, p. 6,082-6,092. doi.org/10.1029/ JB078i026p06082 